University of Wollongong

Research Online

Faculty of Engineering and Information

Faculty of Engineering and Information

Sciences - Papers: Part A

Sciences

$1-1-2013$

\title{
Effect of austenitising and deformation temperatures on dynamic recrystallisation in $\mathrm{Nb}$-Ti microalloyed steel
}

Andrii G. Kostryzhev

University of Wollongong, andrii@uow.edu.au

Abdullah Al Shahrani

University of Wollongong, amfa065@uowmail.edu.au

Chen Zhu

University of Sydney, czhu@uow.edu.au

Simon P. Ringer

University Of Sydney

Elena V. Pereloma

University of Wollongong, elenap@uow.edu.au

Follow this and additional works at: https://ro.uow.edu.au/eispapers

Part of the Engineering Commons, and the Science and Technology Studies Commons

Research Online is the open access institutional repository for the University of Wollongong. For further information contact the UOW Library: research-pubs@uow.edu.au 


\title{
Effect of austenitising and deformation temperatures on dynamic recrystallisation in $\mathrm{Nb}$-Ti microalloyed steel
}

\author{
Abstract \\ An investigation into influence of the austenitising temperature and the austenite deformation \\ temperature on $\mathrm{Nb}$ precipitation and recrystallisation kinetics was carried out for a steel containing \\ $0.081 \mathrm{C}-0.021 \mathrm{Ti}-0.064 \mathrm{Nb}$ (wt. \%). The austenite grain structure was correlated to the dispersive properties \\ of $\mathrm{Nb}$ atom clustering and precipitation. Irrespective of the austenitising temperature, deformation to 0.75 \\ strain at $1075{ }^{\circ} \mathrm{C}$ produced a fully recrystallised microstructure. After deformation at $975^{\circ} \mathrm{C}$, only partial \\ recrystallisation was observed in the samples austenitised at higher temperature, whereas samples \\ austenitised at lower temperature were fully recrystallised. The influence of solute drag and particle \\ pinning effects on the recrystallisation rate is discussed. () (2013) Trans Tech Publications, Switzerland.

\section{Keywords} \\ effect, ti, nb, recrystallisation, steel, dynamic, microalloyed, temperatures, deformation, austenitising \\ Disciplines \\ Engineering | Science and Technology Studies

\section{Publication Details} \\ Kostryzhev, A. G., Al Shahrani, A., Zhu, C., Ringer, S. P. \& Pereloma, E. V. (2013). Effect of austenitising and \\ deformation temperatures on dynamic recrystallisation in $\mathrm{Nb}$-Ti microalloyed steel. Materials Science \\ Forum, 753 431-434.
}




\title{
Effect of austenitising and deformation temperatures on dynamic recrystallisation in $\mathrm{Nb}-\mathrm{Ti}$ microalloyed steel
}

\author{
Andrii G. Kostryzhev ${ }^{1 \mathrm{a}}$, Abdullah Al Shahrani ${ }^{1}$, Chen Zhu ${ }^{2}$, \\ Simon P. Ringer ${ }^{2}$ and Elena V. Pereloma ${ }^{1}$ \\ 1 - School of Mechanical, Materials and Mechatronic Engineering, Faculty of Engineering, \\ University of Wollongong, NSW 2500, Australia
}

2 - Australian Centre for Microscopy and Microanalysis, and School of Aerospace, Mechanical and Mechatronic Engineering, The University of Sydney, NSW 2006, Australia

a e-mail: kostryzhev@yahoo.com

Key words: thermo-mechanical processing, precipitation, recrystallisation, microalloyed steel

\begin{abstract}
An investigation into influence of the austenitising temperature and the austenite deformation temperature on $\mathrm{Nb}$ precipitation and recrystallisation kinetics was carried out for a steel containing $0.081 \mathrm{C}-0.021 \mathrm{Ti}-0.064 \mathrm{Nb}$ (wt. \%). The austenite grain structure was correlated to the dispersive properties of $\mathrm{Nb}$ atom clustering and precipitation. Irrespective of the austenitising temperature, deformation to 0.75 strain at $1075{ }^{\circ} \mathrm{C}$ produced a fully recrystallised microstructure. After deformation at $975{ }^{\circ} \mathrm{C}$, only partial recrystallisation was observed in the samples austenitised at higher temperature, whereas samples austenitised at lower temperature were fully recrystallised. The influence of solute drag and particle pinning effects on the recrystallisation rate is discussed.
\end{abstract}

\section{Introduction}

The $\mathrm{Nb}$ solute atoms and precipitates pin the austenite grain boundaries and reduce the recrystallisation and grain growth rates, which leads to grain refinement and improved mechanical properties. An increase in $\mathrm{Nb}$ content in steel composition retards recrystallisation (the recrystallisation stop temperature, $\mathrm{T}_{\mathrm{nr}}$, increases [1]). $\mathrm{Nb}(\mathrm{C}, \mathrm{N})$ precipitates were shown to pin the grain boundaries stronger than $\mathrm{Nb}$ solute atoms [2 - 4]. However, the $\mathrm{Nb}$ solute drag effect has a significant influence on recrystallisation at high temperatures, low strain levels, short interpass time and high cooling rate $[5,6]$, i.e. when the particle number density is low. Although a significant research was carried out to assess a dependence of the $\mathrm{Nb}$ precipitation kinetics (and related to it the pinning effect strength) on steel composition [1, 7 - 9] and strain levels [10 - 12], no final conclusion was made regarding the optimum precipitation parameters to maximise the grain boundary pinning effect. In the present paper a dependence of the austenite recrystallisation kinetics on the $\mathrm{Nb}$ precipitation kinetics was studied for the $\mathrm{Nb}$-Ti-microalloyed steel.

\section{Material and experimental techniques}

The $\mathrm{Nb}$-Ti-microalloyed steel of composition $0.081 \mathrm{C}, 1.20 \mathrm{Mn}, 0.27 \mathrm{Si}, 0.021 \mathrm{Ni}, 0.019 \mathrm{Cr}$, $0.1 \mathrm{Mo}, 0.016 \mathrm{Cu}, 0.037 \mathrm{Al}, 0.064 \mathrm{Nb}, 0.021 \mathrm{Ti}, 0.003 \mathrm{~V}, 0.001 \mathrm{~S}, 0.012 \mathrm{P}$, and $0.0047 \mathrm{~N}$ (all in wt \%) has been received from BlueScope Steel Ltd. For thermo-mechanical processing (TMP) simulations, samples of $10 \times 15 \times 20 \mathrm{~mm}$ size were cut from a quarter thickness position of a $230 \mathrm{~mm}$ thick continuously cast slab. The TMP was performed using Gleeble 3500 thermo-mechanical simulator (Fig. 1, a). To modify the Nb precipitate size distributions, the steel samples were heated to two temperatures (near the particle dissolution temperature and above it) and deformed at two temperatures (near $\mathrm{T}_{\mathrm{nr}}$ and above it). All the samples were water quenched immediately after the finishing deformation in order to prevent $\mathrm{Nb}$ diffusion. This allowed studying the $\mathrm{Nb}$ clusters and precipitates in austenite. The prior austenite grain boundaries were revealed by etching for $5 \mathrm{~min}$ at $68{ }^{\circ} \mathrm{C}$ in a special reagent (aqueous picric acid + hydrochloric acid + detergent). To obtain the austenite grain size (equivalent circle diameter) distributions, 800-1000 grains were imaged using Leica DMRM optical microscope. For determination of the Nb-Ti-rich particle size distributions and the particle number density values, 2306 particles from all the four TMP conditions were 
imaged using JEOL 7001F FEG scanning electron microscope (SEM). Compositions of 57 particles from all the four TMP conditions were analyzed using energy dispersive X-ray spectroscopy (EDXS). The $\mathrm{Nb}$ atom cluster and $\mathrm{Nb}-\mathrm{C}$ cluster size and number density for all the four TMP conditions were studied using atom probe tomography (APT). The APT data was collected on a Cameca ${ }^{\circledR}$ Local Electrode Atom Probe (LEAP), operating at a temperature of $20 \mathrm{~K}$ and a pulse fraction rate of $20 \%$ [13]. The APT specimen preparation included two stages of electropolishing using a solution of $25 \%$ perchloric $+75 \%$ glacial acetic acid during rough polishing, and a solution of $2 \%$ perchloric acid + 98\% butoxyethanol during fine polishing [14].

\section{Results and Discussion}

Analysis of the stress-strain behaviour during finishing deformation (Fig. 1, b) has shown continues work-hardening for the " $1250{ }^{\circ} \mathrm{C}$ reheating $+975{ }^{\circ} \mathrm{C}$ deformation" TMP schedule, which corresponds to incomplete recrystallisation observed on optical micrographs (Fig. 1, c). However, the other three schedules have shown the gradual decrease in stress after reaching a maximum, which corresponds to the optically observed equaxed grain structures (Fig. 1, d, e, f) and is an indicative of the dynamic recrystallisation. Such a variation in recrystallisation kinetics and stress-strain behaviour might be related to a variation in the $\mathrm{Nb}$ precipitation kinetics with the TMP schedule.

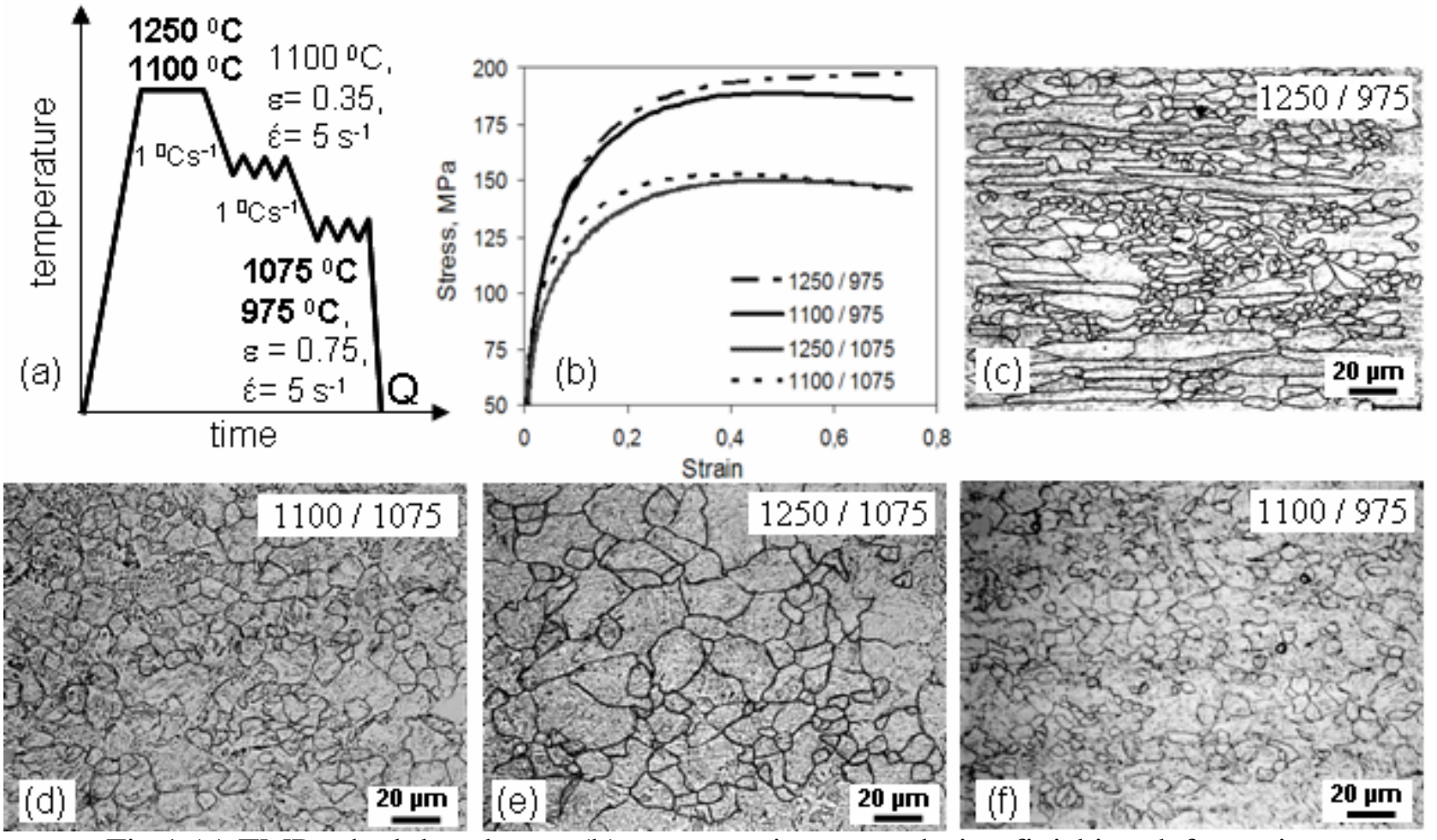

Fig.1 (a) TMP schedule scheme, (b) stress-strain curves during finishing deformation and $(\mathrm{c}, \mathrm{d}, \mathrm{e}, \mathrm{f})$ prior austenite microstructures for the four TMP schedules

The SEM imaging revealed presence of $20-130 \mathrm{~nm}$ precipitates for all the four TMP schedules (Fig. 2, Table 1). Two groups of precipitates have been separated by EDXS: (i) $>70 \mathrm{~nm}$ size ellipsoidal and cuboidal, mainly TiNb-rich; and (ii) $<70 \mathrm{~nm}$ size close to spherical shape, mainly Nb-rich particles. The parameters for $>70 \mathrm{~nm}$ particles did not show a significant variation with the TMP schedule (Table 1), which can be explained by the higher dissolution temperature / time of the particle Ti core compared to the austenitising temperature / time. However, within the $<70 \mathrm{~nm}$ size range with a decrease in austenitising temperature the average particle diameter decreased, the number density increased and the relative amount of the Nb-rich particles (to the total amount analysed) increased. These can be explained by the incomplete dissolution of $\mathrm{Nb}$-rich particles during holding at $1100^{\circ} \mathrm{C}$. With a decrease in deformation temperature both the particle number density within the $<70 \mathrm{~nm}$ size range and the relative amount of $\mathrm{Nb}$-rich particles (to the total 
amount analysed) have increased. This can be explained by the longer time for precipitation (cooling time between the roughing and finishing deformations).
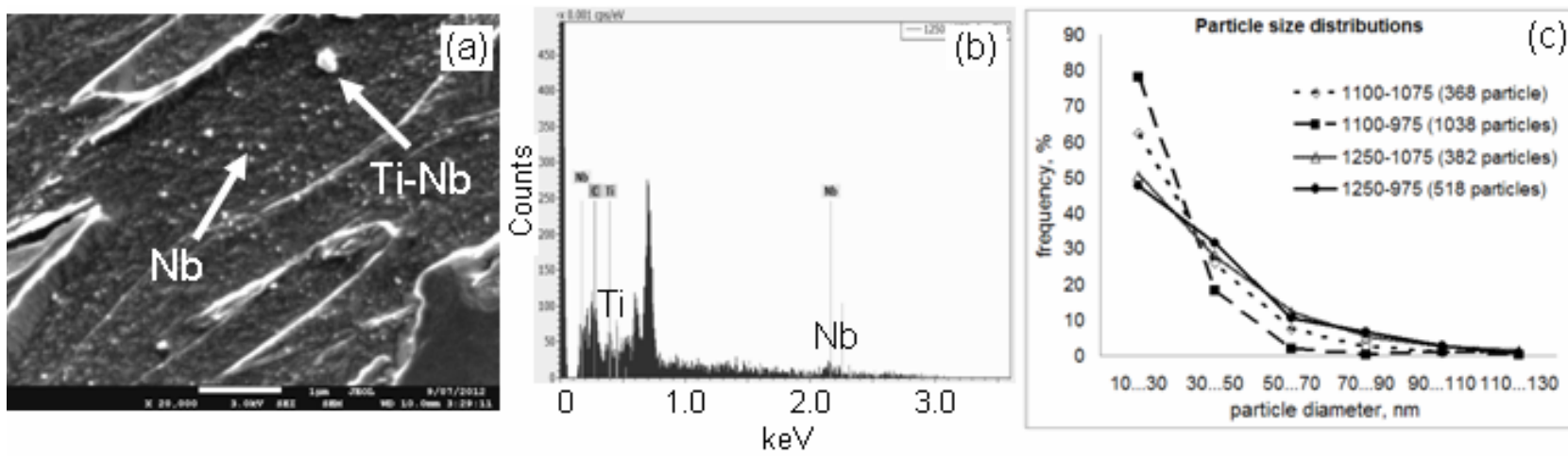

Fig. 2 Typical (a) SEM image of precipitates for " $1100{ }^{\circ} \mathrm{C}$ reheating $+1075{ }^{\circ} \mathrm{C}$ deformation" TMP schedule and (b) EDS spectra of a TiNb-rich particle; (c)- particle size distributions

Table 1 Summary of the parameters for $\mathrm{TiNb}$ - and $\mathrm{Nb}$-rich precipitates

\begin{tabular}{|l|c|c|c|c|c|c|c|c|c|}
\hline Re-heating temperature $\left[{ }^{\circ} \mathrm{C}\right]$ & \multicolumn{3}{|c|}{1100} & \multicolumn{3}{|c|}{1250} \\
\hline Deformation temperature $\left[{ }^{\circ} \mathrm{C}\right]$ & \multicolumn{2}{|c|}{1075} & \multicolumn{2}{|c|}{975} & \multicolumn{2}{|c|}{1075} & \multicolumn{2}{c|}{975} \\
\hline Particle size range $[\mathrm{nm}]$ & $<70$ & $>70$ & $<70$ & $>70$ & $<70$ & $>70$ & $<70$ & $>70$ \\
\hline \multicolumn{2}{|l|}{ Number density $\left[\mu \mathrm{m}^{-2}\right]$} & 3.13 & 0.13 & 12.06 & 0.21 & 2.05 & 0.21 & 2.75 & 0.31 \\
\hline \multicolumn{2}{|l|}{ Average diameter $[\mathrm{nm}]$} & 26 & 96 & 22 & 107 & 29 & 92 & 29 & 84 \\
\hline \multirow{2}{*}{ Chemistry $[\%]$} & $\mathrm{Nb}$ & 57 & 0 & 80 & 0 & 30 & 40 & 50 & 20 \\
\cline { 2 - 10 } & $\mathrm{Nb}-\mathrm{Ti}$ & 43 & 100 & 20 & 100 & 70 & 60 & 50 & 80 \\
\hline
\end{tabular}

The APT study of atom clusters has shown presence of $\mathrm{C}$ clusters, $\mathrm{Nb}$ clusters and $\mathrm{Nb}-\mathrm{C}$ clusters of varying composition (Fig. 3) for all the four TMP conditions. With a decrease in austenitising temperature, the $\mathrm{Nb}$ content in the austenite matrix, the $\mathrm{Nb}$ cluster size and number density and the $\mathrm{Nb}-\mathrm{C}$ cluster number density all decreased, although the $\mathrm{Nb}$-rich particle number density increased (Table 2). These can be related to the incomplete dissolution of $\mathrm{Nb}$-rich particles during holding at $1100^{\circ} \mathrm{C}$. The number densities of $\mathrm{Nb}$ clusters, $\mathrm{Nb}-\mathrm{C}$ clusters and $\mathrm{Nb}$-rich particles all increased with a decrease in deformation temperature, which can be related to an increase in the time available for precipitation.

(a)

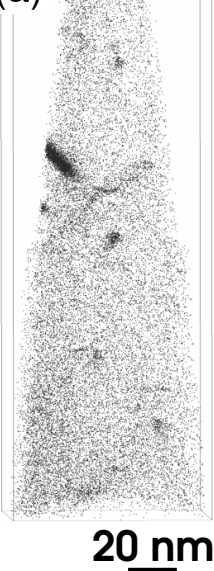

$20 \mathrm{~nm}$ (b) $\because \because \because \therefore$

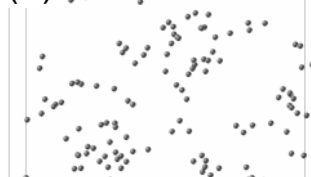

$\therefore \because \because \quad \because \cdots$

$\because \because \because \because \cdots$

$\because \because \because \because \because \theta^{2}$

$\because \therefore \quad \therefore$

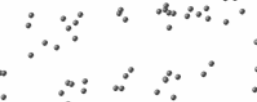

$\therefore \quad \because \because \because$

\section{$10 \mathrm{~nm}$}

(c)

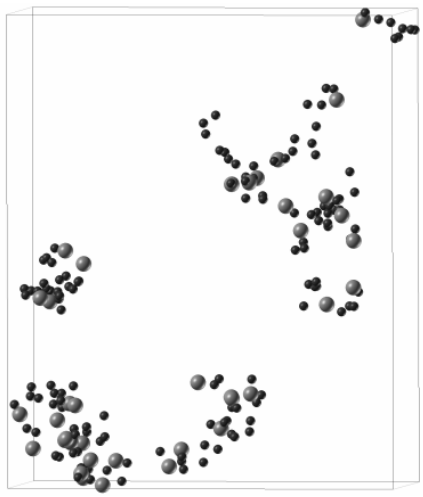

$10 \mathrm{~nm}$ (d)

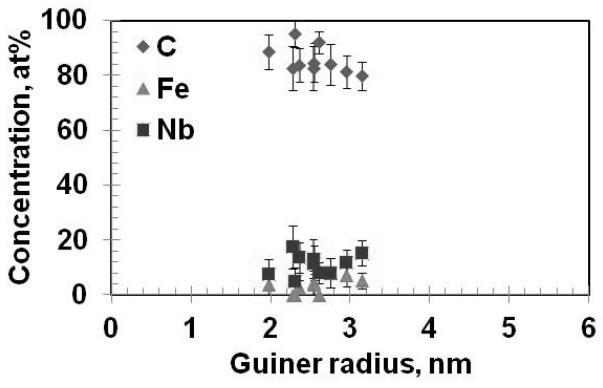

Fig. 3 (a) Carbon atom map and selected atom maps showing (b) Nb clusters and (c) Nb-C clusters ( $\mathrm{Nb}$ - large and $\mathrm{C}$ - small spheres); (d) dependence of $\mathrm{Nb}-\mathrm{C}$ cluster composition on cluster size (all for " $1100{ }^{\circ} \mathrm{C}$ reheating $+1075{ }^{\circ} \mathrm{C}$ deformation" TMP schedule) 
Partial recrystallisation of the austenite grain structure was observed for the TMP condition $\left(1250^{\circ} \mathrm{C}\right.$ reheating $+975{ }^{\circ} \mathrm{C}$ deformation) when the matrix was enriched with $\mathrm{Nb}$ solute atoms, the number densities of $\mathrm{Nb}$ and $\mathrm{Nb}-\mathrm{C}$ clusters were high and this of the $\mathrm{Nb}$-rich particles was low. These may indicate a stronger grain boundary pinning effect from the $\mathrm{Nb}$ atoms and $\mathrm{Nb} / \mathrm{Nb}-\mathrm{C}$ clusters in the $<5 \mathrm{~nm}$ size range, compared to the $\mathrm{Nb}$-rich precipitates in the $>20 \mathrm{~nm}$ size range.

Table 2 Summary of the parameters for $\mathrm{Nb}$-rich precipitates and $\mathrm{Nb}$-containing clusters

\begin{tabular}{|c|c|c|c|c|c|}
\hline \multirow{2}{*}{\multicolumn{2}{|c|}{$\frac{\text { Re-heating temperature }\left[{ }^{\circ} \mathrm{C}\right]}{\text { Deformation temperature }\left[{ }^{\circ} \mathrm{C}\right]}$}} & \multicolumn{2}{|c|}{1100} & \multicolumn{2}{|r|}{1250} \\
\hline & & 1075 & 975 & 1075 & 975 \\
\hline \multicolumn{2}{|c|}{$\mathrm{Nb}$ in the matrix [wt \%] } & 0.002 & 0.005 & 0.016 & 0.015 \\
\hline \multirow{3}{*}{$\begin{array}{l}\mathrm{Nb} \\
\text { clusters }\end{array}$} & Maximum cluster size [number of atoms] & 10 & 8 & 12 & 16 \\
\hline & Maximum Guinier radius [nm] & 2.1 & 1.4 & 1.6 & 1.7 \\
\hline & Number density $\left[\times 10^{5} \mu \mathrm{m}^{-3}\right]$ & 1.60 & 2.15 & 3.19 & 3.74 \\
\hline \multirow{3}{*}{$\begin{array}{l}\mathrm{Nb}-\mathrm{C} \\
\text { clusters }\end{array}$} & Maximum cluster size [number of atoms] & 53 & 72 & 92 & 53 \\
\hline & Maximum Guinier radius [nm] & 3.0 & 3.6 & 4.1 & 3.0 \\
\hline & Number density $\left[\times 10^{5} \mu \mathrm{m}^{-3}\right]$ & 0.20 & 2.0 & 4.3 & 7.0 \\
\hline \multirow{2}{*}{$\begin{array}{l}\mathrm{Nb} \text {-rich } \\
\text { particles }\end{array}$} & Average diameter $(20-70 \mathrm{~nm}$ range $)[\mathrm{nm}]$ & 26 & 22 & 29 & 29 \\
\hline & Number density $\left(20-70 \mathrm{~nm}\right.$ range) $\left[\mu \mathrm{m}^{-3}\right]$ & 3.13 & 12.06 & 2.05 & 2.75 \\
\hline \multicolumn{2}{|c|}{ Austenite grain size $[\mu \mathrm{m}]$} & 10 & 6 & 9 & Partial recrystal. \\
\hline
\end{tabular}

\section{Conclusion}

In the studied $\mathrm{NbTi}$-microalloyed steel the $\mathrm{Nb}$ solute atoms and $\mathrm{Nb} / \mathrm{Nb}-\mathrm{C}$ clusters in the $<5 \mathrm{~nm}$ size range were more effective in retarding recrystallisation than $\mathrm{Nb}$-rich particles in the $>20 \mathrm{~nm}$ size range, due to a much higher number density of the clusters than that of the particles.

Acknowledgement: the authors are thankful to CBMM, BlueScope Steel Ltd., the ARC (LP110100231) for financial support of the project and to the AMMRF for technical support.

\section{References}

1. B. Dutta and C. M. Sellars, Materials Science and Technology, 3 (1987) 197-206.

2. S. Vervynckt, K. Verbeken, P. Thibaux, Y. Houbaert, Materials Science and Engineering A, 528 (2011) 5519 - 5528.

3. H.S. Zurob, G. Zhu, S.V. Subramanian, G.R. Purdy, C.R. Hutchinson and Y. Brechet, ISIJ Int., 45 (2005) $713-722$.

4. C.R. Hutchinson, H.S. Zurob, C.W. Sinclair and Y.J.M. Brechet, Scripta Materialia, 59 (2008) $635-637$.

5. C.L. Miao, C.J. Shang, H.S. Zurob, G.D. Zhang, and S.V. Subramanian, Metallurgical and Materials Transactions A, 43A (2012) 665 - 676.

6. A. J. DeArdo, International Materials Reviews, 48 (2003)371 - 402.

7. B. Dutta, E.J. Palmiere and C. M. Sellars, Acta Materialia 49 (2001) 785-794.

8. Y. Xu, Y. Yu, X. Liu and G. Wang, Journal of Material Science and Technology, 22 (2006) $149-152$.

9. S. G. Hong, K.B. Kang and C.G. Park, Scripta Materialia, 46 (2002) 163 - 168.

10. S. Okaguchi and T. Hashimo, ISIJ International, 32 (1992) 283-290.

11. Y. Zeng and W. Wang, Journal of Material Science, 43 (2008) 874-882.

12. J.-S. Park, Y.-S. Ha, S.-J. Lee and Y.-K. Lee, Metallurgical and Materials Transactions A, 40A (2009) $560-568$.

13. L. Yao, J.M. Cairney, C. Zhu and S.P. Ringer, Ultramicroscopy, 111 (2011) 648-651.

14. B.G. Gault, M.P. Moody, J.M. Cairney, S.P. Ringer, Atom probe microscopy, Springer, 2012. 